\title{
2 Die mensbeskouing van Calvyn
}

\subsection{Die oorsprong van die mens}

Daar is by Calvyn geen twyfel daaroor dat Gód die mens geskápe het nie (Inst. 1.15.1). Dit is vir hom só vanselfsprekend dat hy in sy Institusie byna oor hierdie feit heen beweeg sonder om dit in besonderhede uit te spel. Hy gaan ook onmiddellik daartoe oor om die onderskeid tussen siel en liggaam te behandel (Inst. 1.15.2).

\subsubsection{Kreasianisme en tradusianisme ${ }^{2}$}

Dit is vir Calvyn voldoende om te weet (i) dat die mens geskape is, ook sy siel (die Manicheisme het foutiewelik geleer dat die siel 'n uitvloeisel van God in die mens is, - Inst. 1.15.5), (ii) dat die mens deur God geskape is en (iii) dat hy goed geskape is. Wat die skepping van die siel betref, is dit duidelik dat Calvyn (in navolging van Augustinus) op die standpunt van die kreasianisme (wat van kreasionisme onderskei moet word) staan en nie op dié van die tradusianisme nie elke siel word deur God by konsepsie geskep en vloei nie voort uit die natuurlike proses van menslike voortplanting nie (vgl. Holwerda, 1984:315-316; Faber, $1990: 240,248$ ). "Skepping (van siele) is egter nie oordrag nie maar die begin van wese uit die niet" (Inst. 1.15.5).

Hier sien ons reeds duidelik dat Calvyn die Platoniese psigologie ten opsigte van die oorsprong van die siel deurbreek: die siel van die mens bestaan nie as substansie los vall God van ewigheid af nie maar word in die tyd deur God geskep en met die liggaam verbind (vgl. Faber, 1990:248; Holwerda, 1984:315316). Die dualistiese mensbeskouing, wat ongetwyfeld aanwesig is, word dus vanuit 'n teologiese perspektief (God as Skepper) versag, 'n tendens wat ook ten opsigte van die bestemming van die siel (onsterflikheid) volgehou word - maar daaroor later meer. Dit is egter opvallend dat die Skrif nêrens afsonderlik oor die skepping van die siel handel nie sodat ons hier in 'n groot mate met ' $n$ illegitieme probleemstelling te doen het (Berkouwer, 1957:329).

2 Kreasıanisme kan soos volg omskryf uord Dic "locr dat dic menslike sicl deur 'n besondere daad van God afsonderlik geskep word in elke individu wat gebore word" (WAT, 1991 8:145) Tradusianisme lecr dat dic menslike sicl langs dic weg van natuurlike voortplanting ontstaan 


\subsubsection{Kreasionisme ${ }^{3}$ en ewolusionisme}

Calvyn (1509-1564) het geleef voordat die ewolusionisme in die negentiende eeu na vore gekom het en hy kon hom dus nie daaroor uitspreek nie. 'n Mens kan oor die vraag spekuleer of Calvyn hom, veral in die hig van sy fundamentele Skrifbeskouing, krities oor die ewolusionisme sou uitgelaat het. Dit bly egter 'n feit dat hy hom nie breedvoerig oor die hoe van die skepping van die mens uitgelaat het nie. Dit val egter op hoedat in die dogmatiese ontwikkeling sedert die negentiende en veral twintigste eeu hierdie hoe-vraag en daarmee saam die ewolusionisme breedvoerig aan die orde gekom het (vgl. slegs Bavinck, 1928:475-484; Bavinck, 1978:164 e.v., 174,190 e.v.; Bremmer, 1961:213-216 (i.v.m. Bavinck); Berkhof, 1973:182-185; Heyns, 1978:105-108; Durand, 1982:114-125; Wentsel, 1987:524-531; Duvenage, 1981:115-126; Van Genderen \& Velema, 1992:250-260).

Oor die onderwerp van die ewolusionisme is daar geweldig baie geskryf ${ }^{4}$ (vgl. die bronnelys by Ryke, 1987) en dit sou ons te ver van ons onderwerp wegvoer om op hierdie stadium breedvoerig daarop in te gaan. Ek volstaan dus met 'n aantal kort opmerkings.

As dit waar is dat die meeste natuurwetenskaplikes in die wêreld (Ryke, 1987:344) en die meeste ernstige teoloè (Berkhof, 1973:167) die ewolusieteorie aanvaar, dan spreek dit vanself dat die vraag na die verband tussen skepping en ewolusie ' $n$ diep ingrypende vraag is. Dit is dus begryplik dat van teologiese kant gepoog sou word om skepping en ewolusie met mekaar te probeer versoen en inderdaad het Berkhof so 'n poging onderneem. Onder 'goeie' skepping verstaan hy dan nie ' $n$ volmaakte begintoestand nie maar 'n skepping 'geskik vir sy doel', naamlik vir die omgang tussen God en mens (Berkhof, 1973:180). En die skepping van die mens 'na die beeld van God' beteken dat die mens van God se teenwoordigheid bewus geword het, toe hy bewus geword het dat hy in verhouding tot God staan, met Hom kan kommunikeer, Hom kan liefhê en Hom kan aanbid, toe was die mens méns (1973:191 e.v.). En die sonde dan? Berkhof $(1973: 178,200)$ antwoord dat die sonde, die aggressie, afkomstig is uit die dierewêreld; die mens is 'n 'sosiale roofprimaat' en die selfhandhawingsdrang stam uit die diereryk (Berkhof, 1973:218). Sonde is die skuldige beswyking voor

3 Met kreasionisme word skepping (tecnoor ewolusic) geimplisecr Kreasıonisme is "dic lecr of teorie dat materic, die verkillende vorme van lewe en bewussyn deur ' $n$ transendente God uit niks geskep is" (WAT, 1991 8:145). Livingstone, 1987, Ryke, 1987, Berghocf \& De Koster, 1988; Berry. 1988 
die swaartekrag van ons natuurlike agtergrond; dit is nie ' $n$ val vanuit ' $n$ hoëre werklikheid nie, maar die weiering om te styg na die hoëre werklikheid van die liefdesgemeenskap met God (Berkhof, 1973:219).

Van die grootste teologiese probleme rondom ewolusie raak nie net die oorsprongs- en toekomsvrae van die mens nie, maar veral die vrae in verband met sonde en genade, val en verlossing, met ander woorde die vraag na die plek en werk van Jesus Christus.

Waar pas Christus en sy verlossing in die ewolusieproses in? Word daar nie minimaliserend oor die werk van Christus geoordeel nie? - hoewel pogings om die Christologie/soteriologie en ewolusionisme met mekaar te versoen nie uitgebly het nie (vgl. Segundo, 1988). Dit kan nie ontken word nie dat die ewolusionisme permanent bedreig word deur 'n sinergistiese motief - of erger nog - 'n tendens tot selfverlossing, wat uiteindelik op deiffikasie van mens sou kon uitloop. Juis daarom is dit so belangrik om op die teoretiese en voorlopige karakter van die ewolusionisme klem te lê.

In 'n besinning oor die vraagstuk van die ewolsionisme moet teen twee gevare gewaak word: enersyds kan die Bybel as natuurwetenskaplike handboek hanteer en dus oorvra word en andersyds kan die wetenskaplike resultate oorspan word as feillose feite terwyl van die voorwetenskaplike vertrekpunte ook nie deeglik rekenskap gegee word nie (vgl. Popına, 1969). Die Bybel is 'n geloofshoek en dis binne hierdie raamwerk dat die Bybelse skeppingsgeskiedenis verstaan moet word (vgl. Kalsbeek, 1968:68). Natuurlik is dit waar dat God op enige wyse kon geskep het, ook op ewolusionêre wyse (Duvenage, 1981:124), hoewel die Bybel dit nie uitspel nie. Die Bybel vertel ons dat God geskep het, die wetenskap help ons om die hoe daarvan te begryp (Ryke, 1987:337, 343; Berkhof, 1973:182-185).

Ten opsigte van die ewolusievraagstuk is daar drie standpunte: kreasionisme (skepping in plaas van ewolusie), ateïstiese ewolusionisme (ewolusie in plaas van skepping) en teïstiese 'ewolusionisme' (skepping deur ewolusie). Waar eersgenoemde standpunt mank gaan aan 'n fundamentalistiese Skrifgebruik en 'n onderwaardering van die wetenskaplike navorsing, en die tweede standpunt direk in stryd is met die Christelike geloof, daar is die derde standpunt besig om al hoe meer veld te wen, al is hierdie standpunt ook nie sonder bepaalde probleme nie (vgl. Ryke, 1987; Berkhof, 1973; Lever, 1969; Lever, 1985). Dit kan myns insiens bevraagteken word of die standpunte van Lever en Du Toit werklik so ver van mekaar verskil. Lever handhaaf dat ewolusie onder leiding van God plaasvind en Du Toit, met sy standpunt van 'transendentale progressiewe kreasie', dat die skepping deur God 'n lang ewolusionêre proses deurloop (vgl. Du Toit, 1968:375 e.v.). Dit skyn ook of Du Toit (1968:143-147) se siening van retrospektiewe (terugskouende) profesie ten opsigte van die protologie (Genesis), na 
analogie van die antisiperende (vooruitskouende) profesie oor die eskatologie (Openbaring), toenemend nagevolg word (Durand, 1982:120).

Die Christelike geloof sal hom blywend verset teen ewolusie-as-dogma (en nie soseer teen die ewolusie-as-teorie nie). Daarom moet daar goed onderskei word tussen die feite van die ewolusie en die filosofie van die ewolusionisme (Bavinck, 1978:192), tussen ewolusie en die ewolusieleer (Durand, 1982:122), tussen die ewolusieleer as ' $n$ wetenskaplike teorie en die ewolusionisme as 'n wêreldbeskouing (Van Genderen \& Velema, 1992:257). Ateïstiese ewolusionisme, met sy materialistiese lewens- en wêrelbeskouing is in die lig van die Skrifgetuienis ten enemale onaanvaarbaar. Die Christelike geloof sal egter op sy hoede moet wees om ten opsigte van die mensbeeld nie dieselfde fout te begaan as wat opsigte van die (geosentriese) wêreldbeeld begaan is deur een teorie as die finale en volmaakte voor te hou nie (Durand, 1982: 124). Al ons kennis, ons teologiese én ons natuurwetenskaplike kennis, is 'ten dele' (1 Kor. 13:12) en eers hierna sal ons oor volmaakte kennis beskik. Waarvan ons nóu reeds seker kan wees, is dat die openbaring van God in die Skriftuur en sy openbaring in die natuur mekaar nie kan weerspreek nie aangesien dit die openbaring is van die één God (De Bondt, 1949:206; Berkhof, 1973:184). Die Skrif is sy eie uitlêer, maar die wetenskap kan soms ' $n$ bydrae lewer om die Skrif beter te verstaan (Berkhof, 1973:184; Oosterhoff, 1972:50,52,54,57).

\subsubsection{Reinkarnasie}

Dit is haas onnodig om te noem dat die gedagte van die reïnkarnasie van die siel so ver buite die denkwêreld van Calvyn - en die Christelike geloof - geleë is dat daaraan nie verder aandag bestee word nie. Gelukkig het Calvyn nie die leer van die sielsverhuising van Plato in sy teologiese denke opgeneem nie (siele wat eerbaar gelewe het, keer na die sterrewêreld tenug maar dié wat sleg gelewe het, word in laere wesens (diere) gereinkarneer totdat hulle verbeter het). Die reinkarnasieleer is van baie ou oorsprong - dit is reeds lank voor Christus in die Boeddhisme aangetref - en dit het in die jongste tyd 'n nuwe stimulus vanuit die New Age-beweging ontvang.

\subsection{Die wese van die mens}

Een van die grootste probleme in verband met die mensbeskouing van Calvyn raak die wese van die mens, veral soos dit in verband staan met die mens as beeld van God (imago Dei) en die siel-liggaam-digotomie. Dit val op dat Calvyn in die Institusie selfs met die siel-liggaam-digotomie begín (Inst. 1.15.2) vóórdat hy oor die mens as beeld van God gaan handel (Inst. 1.15.3-4) om daarná weer na 'n bespreking van die siel terug te keer (Inst. 1.15.5-8). 


\subsubsection{Mens en God}

Dit is duidelik dat die hoofsom van menslike wysheid vir Calvyn in kennis van God en kennis van die mens bestaan (Inst. 1.1.1). Die mens kan dus nie buite sy verhouding tot die lewende God reg verstaan word nie sodat kenners van oordeel is dat die beeld nie net met voortreflikhede in die mens verbind moet word nie, maar ook met die mens se relasie tot God (Torrance, 1977:29; Gerrisch, 1984:115). (Esser (s.j.:22-40) meen dat Calvyn nog te veel aan die voortreflikhede vashou.) Veral in sy preke oor Job blyk dit duidelik dat die beeld nie net te doen het met die mens se natuur nie maar met sy besondere verhouding tot God (Torrance, 1977:80). Die mens bestaan coram Deo en hierdie geheim vind uitdrukking in die bekende uitspraak dat die mens geskape is na die beeld van God (vgl. Wallace, 1961:105).

Die uitspraak dat die mens geskape is na die beeld van God laat egter 'n hele reeks vrae ontstaan: Waarin het die beeld oorspronklik bestaan? Waar vind ons die beeld? Wat was die effek van die sondeval op die beeld en is die gevalle mens nog steeds beeld? Hoe word die beeld herstel? Wanneer sal die vemuwing voltooi wees? (vgl. Hoekema, 1988:42-49). Hierdie vrae gaan dus oor die mens as skepsel, as sondaar, as verloste en as vernude mens.

\subsubsection{Die beeld voor die sondeval}

Die eerste vraag wat hier beantwoord moet word, is die vraag waarin die beeld voor die sondeval bestaan het. By 'n beantwoording van hierdie vraag moet in gedagte gehou word dat beeld en gelykenis vir Calvyn basies sinonieme begrippe is (Inst. 1.15.3; Comm. Gen.1:26) en dat hy die beeld ook op engele sowel as op die man én vrou betrek (1.15.4).

Calvyn se omskrywing van die beeld van God is veelseggend: beeld gaan vir hom "oor die uitstraling van die heerlikheid van God" in die mens (Inst. 1.15.3). Beeld dui op die "reinheid waarmee Adam bedeel was toe hy 'n regskape verstand gehad het en begeertes wat na sy rede geskik was, terwyl al sy sinne in onderlinge harmonie was en hy in sy uitnemende gawes waarlik die uitnemendheid van sy Skepper uitgedruk het" (Inst. 1.15.3); Comm. The Book of Psalms 8:5). Dit is duidelik dat Calvyn die imago betrek op die "kenmerke van uitnemendheid waarmee God Adam van ander lewende wesens onderskei het": "Die mens is dus na die beeld van God geskep, omdat die Skepper sy eie heerlikheid soos in 'n spieël in hom wou laat sien" (Inst. 2.12.6). Die motief van 'n "spieëlbeeld van die heerlikheid van God" kom telkens na vore (Inst. 1.15.4; Comm. Ef. $4: 24$, Col. 3:10). Hoewel Calvyn die Christologiese en antisiperende benadering van Osiander afwys wat sê dat die mens na die beeld van God geskep is "omdat hy dan na die voorbeeld van die toekomstige Christus gevorm wou wees" (Inst. 
2,12.6) (vgl. in dié verband ook Barth, 1959:47,58) ontneem dit Calvyn nie die goeie reg om retrospektief vanuit die Nuwe Testament (verlossing) na die $\mathrm{Ou}$ Testament (sondelose staat) terug te kyk nie. Paulus verbind die hernude beeld met kennis, geregtigheid en heiligheid (Kol. 3:10; Ef. 4:24). "Daaruit kan ons aflei dat die beeld van God in die begin in die verligting van die verstand en regskapenheid van hart geleë was en dat die beeld van God in die ongeskondenheid van al sy dele merkbaar was" (Inst. 1.15.4). Die beeld van God dui op "the rectitude and integrity of the whole soul, so that man reflects, like a mirror, the wisdom, righteousness and goodness of God" (Comm. Col. 3:10).

\subsubsection{Die setel van die beeld (siel en liggaam)}

Uit Calvyn se formulerings is dit duidelik dat hy die beeld nie net betrek op die verhouding van die mens tot God nie maar ook - ons kan selfs sê voor alles - op voortreflikhede in die mens, meer in besonder die siel van die mens. Dit sou egter ' $n$ vertekening van Calvyn wees om te meen dat hy die beeld slégs met die siel en die hoëre sielvermoëns verbind (vgl. Berkouwer, 1957:76).

Hoewel Calvyn stel dat die "eintlike setel" van die beeld die siel is (Inst. 1.15.3) en dat die beeld die "innerlike goed van die siel" is (Inst. 1.15.4) en dat die beeld in die siel "ingegrif" is (Inst. 1.15.5), en hy Osiander afwys wat die beeld "sonder onderskeid" na die siel én liggaam uitbrei, maak hy tog ook die volgende opvallende uitspraak: "En hoewel die setel van die goddelike beeld primêr in die mens se verstand en sy hart of in sy siel en die vermoëns daarvan gesetel was, was daar tog geen deel - en selfs sy liggaam val daaronder - waarin daar nie ' $n$ vonkie van die beeld van God geglinster het nie" (Inst. 1.15.3; Comm. Gen. 1:26). Ook later (in sy Christologie) sou Calvyn hierdie standpunt herhaal (Inst. 2.12.7). (Simpson vestig in ' $n$ voetnoot by 1.15 .4 die aandag daarop dat Calvyn vroeër in sy Psychopannychia die liggaam volkome uitgesluit het.)

Engel (1988:42-47) is van mening dat Calvyn vanuit die perspektief van God die beeld op die volle mens betrek, maar vanuit 'n menslike perspektief word die beeld veral op die siel, as helder beeld, en op die liggaam, as dowwe beeld, betrek.

\subsubsection{Die beeld na die sondeval}

Een van die grootste strydpunte onder navorsers van Calvyn gaan oor die vraag hoe Calvyn enersyds kan volhou dat die sondeval die mens radikaal en totaal aangetas het (corruptio tolalis) maar andersyds nog van oorblyfsels van goedheid in die mens kan praat (residua). Verskeie teoloë het oortuigend en na deeglike navorsing aangetoon dat hierdie tweepoligheid (of dit ' $n$ teenstrydigheid is, is weer ' $\mathrm{n}$ ander vraag) by Calvyn terug te vind is (vgl. onder andere Torrance, 1977:83-115; Hoekema, 1988:42-49; Bouwsma, 1988:139-143; Faber, 1990: 
251-264). Soms vind ons albei aspekte in een en dieselfde sin verwoord, soos byvoorbeeld in die volgende aanhaling gesien kan word:

Hoewel ons daarom toegee dat die beeld van God nie volkome in hom tot niet gemaak en uitgewis is nie, was dit nogtans so bedon'e dat die oorblyfsels daarvan verskriklik misvorm is (Inst. 1.15.4; Comm. Gen. 1:26. My kursiverings - JHvW).

In sy Christologie gaan Calvyn dieper op die tweepoligheid in. In sy afwysing van die oordeelsvryheid van die mens (Inst. 2.2.12) sluit hy aan by Augustinus se onderskeiding van "natuurlike gawes" (verstand, oordeelsvermoë en wil) en "bonatuurlike/geestelike gawes" (geloof, liefde, geregtigheid en heiligheid. Eersgenoemde is "bederf" maar laasgenoemde is "uitgeblus". Die rede van die mens is "nie heeltemal vernietig nie" maar "verswak" en "bedorwe" en lyk soos 'n misvormde bouval. In die bedorwe en ontaarde natuur van die mens "skitter nog vonkies". "Om die verstand tot ewige blindheid te verdoem sodat 'n mens geen begrip van enigiets daarvoor laat nie, is nie alleen strydig met die Woord van God nie maar ook met die bevinding van alınal se ervaring."

Calvyn hanteer ook die onderskeiding van "laer / aardse dinge" en "hoër / geestelike sake" (Inst. 2.2.13) en betrek by hoër of geestelike sake aspekte soos kennis van God, ware geregtigheid, geluksaligheid, koninkryk en toekomstige lewe, terwyl by laer of aardse dinge sake soos regering, ekonomie en kunste tuishoort. By aardse dinge is die mens nie van die lig van die rede beroof nie. "Ons moet nie dink dat die mens se natuur ten volle bedorwe is nie" (Inst. 2.3.3). Ten opsigte van die kennis van God en sy guns teenoor die mens is die mens egter "blinder as 'n mol" (Inst. 2.2.18; vgl. 2.5.19). Wanneer die mens egter ten opsigte van aardse dinge die goeie kies, is dit vanweë God se "besondere genade" en sy voorsienigheid (Inst. 2.4.6). Calvyn gebruik die begrippe "algemene genade" en "besondere genade" identies en betrek dit op gawes wat God aan individuele mense in hulle gevalle staat uitdeel (Inst. 2.2.17;2.3.4). So is daar te midde van al die bedorwenheid ruimte vir God se genade, nie om die bedorwenheid te suiwer nie, maar om dit in bedwang te hou (Inst. 2.3.3).

Calvyn gebruik dus 'n hele reeks begrippe om die 'totale verdorwenheid' van die mens tot uitdrukking te bring: deleta, exstincta, obliterata, spoliatio (vgl. ook Engel, 1988:57/69). (Wallace (1988:224) meen egter dat Calvyn self nie die uitdrukking 'totale verdorwenheid' gebruik het nie.) Andersyds hanteer Calvyn begrippe wat dui op 'n nie-totale komupsie (misvorm, verswak, bedorwe) en selfs op oorblyfsels van goedheid: nie volkome tot niet, nie heeltemal vernietig, nie volkome blind, nie ten volle bedorwe, oorblyfsels, vonkies (vgl. Engel, 1988:58, 70; Smit, 1991:106, 114) 
Moet ons nou hieruit konkludeer dat Calvyn homself weerspreek het of het hy die totale korrupsie geminimaliseer (vgl. Smit, 1991:117)?

Vir 'n juiste verstaan van Calvyn se denke het verskeie navorsers op belangrike toeligtende en verklarende aspekte gewys. So vestig Torrance die aandag daarop dat Calvyn die antropologie in noue samehang met die Christologie behandel: omdat ons van 'totale genade' praat, kan ons ook van 'totale verdorwenheid' praat (Torrance, 1977:20,83,85; ook Rebel, 1981:178). Hierby moet altyd onthou word dat Calvyn, anders as die Skolastiek en Rome, van mening was dat ook die natuurlike gawes besmet is sodat ook die 'reste' deel het aan die totale korrupsie (Torrance, 1977: 83-115; Hoekema, 1988:46; Faber, 1990:262). Dit is van die uiterste belang om hier goed te verstaan dat Calvyn onder 'totale bedorwenheid' verstaan het dat sowel die bonatuurlike as natuurlike gawes - dit wil sê die gánse mens, en nie net die bonatuurlike deel nie - aangetas is (Bouwsma, 1988:139). Totale verdorwenheid sien dus nie daarop dat die mens só verdorwe is dat hy ontmens is nie, maar daarop dat daar geen deel van die mens is wat nie deur die sonde aangetas is nie en dus ongerep gebly het. Die oorerflike boosheid het "oor al die dele van ons siele" versprei (Inst. 2.1.8). "Die mens is in sy geheel van sy kop tot tone soos deur ' $n$ stortvloed begrawe, sodat geen deel vry is van die sonde nie" (Inst. 2.1.9). Bouwsma (1988:142) wys verder daarop dat ten opsigte van die skynbare ambivalensie by Calvyn daar deeglik rekening gehou moet word met sy retoriese styl. Die oorblyfsels van die beeld word ook ter sprake gebring om die mens alle verskoning te ontneem (Rom. 1:20) en verder wou Calvyn hiermee onderstreep dat die mens ook na die sondeval nog méns gebly het (Faber, 1990:259, vgl. Rebel, 1981:177). Die oorblyfsels is dus nie bedoel om die totale korrupsie te relativeer nie maar juis om dit te aksentueer (Faber, 1990:257-258; ook Berkouwer, 1957:132; Noordegraaf, 1990:75, vgl. Polman, s.j.:148).

Dit is dus heeltemal eensydig om soos D'Assonville (1990:102-103) in sy afwysing van menseregte, met slegs ' $n$ enkele verwysing na een kommentaar van Calvyn, te oordeel dat volgens Calvyn die beeld total vernietig is. By ' $n$ behandeling van die sesde gebod kan Calvyn sê dat ons die beeld van God wat op die mens "afgedruk" is, moet eerbiedig (Inst. 2.8.40); liefde tot die naaste sluit álle mense in omdat almal beeld van God is (Inst. 3.7.6;); ons moet daarom álle mense sonder onderskeid liefhê (Inst. 2.8.55). Sowel in sy verklaring van Genesis 9:6 (Comm. Gen. 9:6) as Jakokus 3:9 (Comm. James 3:9) sê Calvyn dat as iemand hier sou teenwerp dat die beeld van God deur die sonde uitgewis is, daar in gedagte gehou moet word dat daar nog wonderbaarlike oorblyfsels oor is. Kolfhaus $(1949: 332,343,352)$ is heeltemal in die kol met sy opmerking dat Calvyn, hoewel hy volksliefde gebillik het, hy rassisme duidelik afgewys het. Hoogs twyfelagtig is daarom ook die standpunt van die filosoof Taljaard $(1976: 159)$ as hy in sy pleidooi vir die opbou van 'n 'teologie van haat' die vol- 
gende sê: "It is therefore absolutely wrong to say that one should love every human being because he was created in the image of God." Taljaard fouteer hier na twee kante toe. Eerstens mag en moet daar gehaat word, niè die sondaar nie maar die sonde - dit het Calvyn ons geleer (Inst. 3.4.34, 4.12.10) in ooreenstemming met die Nuwe-Testamentiese getuienis. Tweedens leer die Nuwe Testament ons ook om selfs ons vyande lief te hê (Matt. 5:44). Hier sien ons tot watter verontrustende konsekwensies die standpunt van 'n verlore beeld (Taljaard, 1976:157, 159) kan lei.

Dit is reeds genoem dat die mens ook na die sondeval nog méns gebly het, geválle mens, maar méns. Hierdie standpunt van Calvyn is in die nareformatoriese teologie voortgesit (vgl. Bavinck, 1928:515; 1978:210; Polman, s.j.:140, 147, 148; Heyns, 1978:127; Hoekema, 1988:72, 83, 98; Hughes, 1989:65-69) en het ook in die refornatoriese belydenisskrifte neerslag gevind waar sprake is van "klein oorblyfsels" van die voortreflike gawes van God (Nederlandse Geloofsbelydenis art. 14) en van "die lig van die natuur" (Dordtse Leerreëls 3/4:4) (vgl. Faber, 1990:278-279, 264).

Wat hierdie siening betref, het daar in die jongste tyd ' $n$ wending gekom. So vra Berkouwer (1957:148-154) of die Ou en Nuwe Testament dan nie die totale verdorwenheid van die mens leer nie. Die vraag kan ook gevra word of die 'oorblyfsel'-motief nie maklik ' $n$ invalspoort vir Pelagianisıne en humanisme kan word nie (1957:63) en wat die aard van die bewaarde humaniteit is (1957:51). Met hierdie vrae wys Berkouwer dus die resgedagte van die hand. Durand $(1982: 167,168)$ stem met Berkouwer saam en wys daarop dat die Nuwe Testament nie getuig van 'n stukkie oorgeblewe beeld nie omdat die beeld deur die sonde verloor is. Ook König (1990:36) volg hierdie denklyn. Hoewel die mens die beeld volgens die Ou Testament nie kan verloor nie, kan dit volgens die Nuwe Testament gebeur en hét dit inderdaad gebeur (König, 1990:37, 40, 59, 159).

Die vraag is hoe hierdie dilemma van verliesbaarheid/onverliesbaarheid van die beeld opgelos moet word, veral soos dit in verband staan met die radikaliteit van die sonde en die totaliteit van die menslike sondeval. Engel (1988:54-61) soek die oplossing in 'n perspektiwiese benadering: vanuit die perspektief van God as regter en verlosser is die beeld totaal verlore, maar vanuit die perspektief van die mens kan van oorblyfsels van die beeld gepraat word.

Whereas from the perspective of God as judge total depravity meant that all of God's gifts are totally lost in the Fall, from the perspective of humankind total depravity means that the totality of the self is affected by sin (Engel, 1988:59).

Oor hierdie probleem van verdorwenheid word vervolgens 'n aantal opmerkings gemaak. 
* Eerstens moet hier in gedagte gehou word dat die Ou Testament nêrens daarvan melding maak dat die beeld vanweë die sonde 'verloor' is nie (Von Rad, 1966:161; Vriezen, 1966:447; vgl. Du Toit, 1963:210). Trouens, die beeld-gedagte as sodanig figureer relatief min in die Ou Testament en die presiese inhoud daarvan word ook grotendeels verswyg (Durand, 1982:163, 164, 167). Blykbaar ken ook die Nuwe Testament nie die problematiek van 'n beeld wat 'verloor' is nie sónder om daarmee die radikaliteit van die sonde in die minste in gedrang te bring (vgl. 2 Kor. 3:18; Ef. 4:24; Kol. 3:10).

* Tweedens val dit op dat sowel die Ou Testament (Gen. 9:6) as die Nuwe Testament (Jak. 3:9) sonder spanning handel oor die mens as beeld van God ook ná die sondeval.

* Derdens moet die vraag beantwoord word waarin die algemeen aanvaarde onaantasbaarheid van die mens dan bestaan indien dit nie direk verband hou met die feit dat die mens beeld van God is nie.

Indien aanvaar sou word dat slegs Christene die beeld van God vertoon en dat dit by nie-Christene volkome afwesig is, het so ' $n$ standpunt vir die etiek verreikende (en verwoestende) gevolge. Die onaantasbaarheid van die mens as mens is dus myns insiens onlosmaaklik daarmee verbind dat hy beeld van God is. Dit is waar dat die sonde die mens struktureel en funksioneel radikaal aangetas het, maar dit is nie waar dat die mens daarmee opgehou het om méns te wees nie (vgl. Pöhlmann, 1980:166, 167). Die mens bly in relasie tot God staan, hetsy positief, hetsy negatief. Die mens kan sonder die relasie tot God nie reg verstaan word nie, of hy nou op God gerig lewe of van God af weg gerig (vgl. Noordegraaf, 1990:73-77; Velema, 1992:302-304, 308, 338.

Ten einde uitdrukking te gee aan enersyds die radikaliteit van die sonde en andersyds aan die onaantasbaarheid van die mens as mens-in-verhouding-totGod, het verskeie teoloê verskillende onderskeidinge probeer invoer: bonatuurlik/ natuurlik (Augustinus, Calvyn), ruimer/enger (Bavinck), formeel/materieel (Brunner), struktureel/funksioneel (Hoekema). Hierdie onderskeidinge is in 'n groot mate skolasties van aard en het by vele tereg kritiek uitgelok (Berkouwer, 1957:35, 37, 38; Durand, 1982:168; vgl. Polman, s.j.:148), maar die intensie daarvan is waardevol (Van Genderen, 1988:113). Die mens kom van die lewende God nooit los nie en hy sal in genade die deugde van God reflekteer of in sonde deflekteer (vgl. Van der Walt, B.J. 1989:148).

Na hierdie ietwat lang omweg is dit nodig om weer na Calvyn terug te keer en aandag te gee aan die herstel van die beeld in Christus. 


\subsubsection{Die beeld na die verlossing (Christus en die Gees)}

Dit is sonder meer duidelik dat Calvyn (Inst. 1. 15.4) die herstel van die beeld onlosmaaklik aan Christus verbind: "Die begin van die herwinning van ons. saligheid is daarom gelee in die herstel wat ons deur Christus verkry." "Die doel van ons wedergeboorte is daarin geleë dat Christus ons weer na die beeld van God vorm." Christus self is die volmaakste beeld van God en wanneer ons na Hom geformeer is, "word ons so vernuwe dat ons die beeld van God in ware godsvrug, geregtigheid, reinheid en kennis kan dra'. 'Heiligheid' dui dan op die mens se verhouding tol God (eerste tafel van die Wet) en 'geregtigheid' op die mens se verhouding tot sy medemens (tweede tafel) (Comm. Ef. 4:24).

In sy pneumatologie kom Calvyn op hierdie aspekte van 'heiligheid' en 'geregtigheid' terug. Hy wys daarop dat wanneer die filosowe mense tot 'n voortreflike lewe wil aanspoor, hulle mense aanmoedig om "in ooreenstemming met die natuur" te lewe. Die Skrif, daarenteen, wys ons daarop om ons lewe aan God oor te gee en Christus (deur wie ons met God versoen is) as voorbeeld na te volg en om "sy beeld in ons lewe tot uitdrukking te bring" (Inst. 3.15.4). Christus vervul dus 'n dubbele funksie: Hy is naas Versoener (wat die mens met God versoen) ook Voorbeeld (van 'n goeie lewe) (Inst. 3. 6.3) - 'n dikwels vergete aspek in die na-reformatoriese teologie. Gelykvormigheid aan Christus word dan onder andere met (die bereidheid tot) martelaarskap in verband gebring (Inst. 3. 9.6).

Dit is waar dat die antropologie (en hamartologie) van Calvyn nie los van die Christologie reg verstaan kan word nie (Niesel, 1980:70), maar dit is ewe waar dat dit ook nie los van die pneumatologie (en eskatologie) korrek geïnterpreteer kan word nie (Rebel, 1981:182). Daarom is daar tereg op gewys dat Calvyn die restourasie van die beeld ook met die werk van die Heilige Gees in verband bring - die Helige Gees wat deur die evangelie werk en die geloof in die harte wek (Hoekema, 1988:46-47; Faber, 1990:268-270). Geloof gaan oor bekering en wedergeboorte, oor die doding van die ou natuur (mortificatio) en die opstanding van die nuwe natuur (vivificatio) (Inst. 3.3.5-8). Onder 'berou' verstaan Calvyn dieselfde as 'wedergeboorte' "waarvan die doel net is om die beeld van God wat deur Adam se oortreding verontreinig en byna uitgewis is, weer in ons te laat vorm kry" (Inst. 3.3.9).

Hiedie proses van bekering is nooit afgeloop nie maar duur die hele lewe lank (Inst. 3.3.2,9,18,20) totdat die voltooiing aanbreek. 'Hoe langer hoe meer' moet die gelowige na Christus toe groei en die beeld van God vertoon. Nie dat volmaaktheid hier ooit bereik sal word nie - Calvyn het die perfeksionisme afgewys - maar wel moet naarstig daana gestreef word (Inst. 3.6.5). 
König het in hierdie verband 'n belangrike bydrae gemaak deur die uitdrukking 'soos-God-wees' van Genesis 3:5 nie net, soos gebruiklik (vgl. Berkhof, 1973: 203; Berkouwer, 1957:106) in malam partem met die sonde in verband te bring nie maar ook bonam partem met die (herstelde) beeld van God. Op talle plekke in die Skrif word die mens tewens opgeroep om 'soos God te wees', nie lángs Hom of in sy plek nie, maar ónder Hom en in sy diens (König, 1990:188-190). Die gelowige word opgeroep om sóós die Vader "volmaak" te wees (Matt. 5:48); sóós die Vader "barmhartig" te wees (Luk. 6: 36); sóós Christus te dien (Joh. 13:15; Mark. 10:43-45); sóós Christus lief te hê (Joh. 13:34; vgl. Ef. 5:2); sóós God te vergewe (Ef. 4:32; vgl. Kol. 3:13); en sóós God 'heilig' te wees (1 Pet. 1:15). Langs hierdie weg verkry die mens uiteindelik deel aan die goddelike natuur (2 Pet. 1:4), 'n sienswyse wat nie verkeerdelik as vergoddeliking van die mens (apoteose) verstaan moet word nie, maar as 'n lewe in liefde volgens die styl van die lewende God. Deel hê aan die goddelike natuur sien nie op 'n opgaan in die wese (essensie) van God nie maar op ' $n$ ingaan in sy eksistensie as ' $n$ bestaan in liefde, heiligheid, geregtigheid en onverderflikheid.

Die uiteindelike bestemming van die mens kom weldra aan die orde wanneer spesifiek daaroor gehandel word.

\subsubsection{Man en vrou (medemenslikheid)}

In hierdie studie is dit nie die bedoeling om breedvoerig te handel oor hoe Calvyn die man-vrourelasie gesien en ontwikkel het nie, ook nie hoe hy oor die plek van die vrou in die kerk geoordeel het nie (vgl. Douglass, 1985). Wat ter sake is, is die vraag na die man-vrourelasie soos dit verband hou met die beeld van God. En dan val dit op dat Calvyn nie hierdie relasie met die beeld in verband bring soos later vrywel eenparig deur reformatoriese teoloë gedoen is nie (Bavinck, 1978:206; Berkouwer, 1957:195; Heyns, 1970:100-101; 1978:126; Berkhof, 1973:197; Wentsel, 1987:594; Hoekema, 1988:74, 76-78) sodat by Barth (1957:217-220) die beeld feitlik in hierdie relasie opgaan. Ander het weer in die motief van medemenslikheid die resultaat van die beeld gesien (Durand, 1982:164). Waarskynlik is Bieler (1963:47) een van die weiniges wat hier tog ' $n$ verband ontdek het as hy opmerk dat "soos die Goddelike wese in die eenheid van sy wese uit verskillende persone bestaan, so is die man en die vrou twee komplementêre manifestasies van dieselfde wese, die menslike skepsel." (vgl. Bieler, 1963:47. Vgl. ook Torrance, 1977:45.)

Wel was dit vir Calvyn duidelik dat sowel die man as die vrou beeld van God is (Inst. 1.15.4).

In alle medemenslike verhoudinge - ook teenoor die vyand - geld die gebod van naasteliefde onvoorwaardelik volgens Calvyn (Inst. 3.8.55-56). Dit wat die 
swaarste weeg ten opsigte van die wet is immers die reg, die barmhartigheid en die trou (Inst. 2.8.52). Vir die armes het hy 'n besondere oog gehad. As ons glo dat die hemel ons bestemming is, sê hy (Inst. 3.18.6), dan moet ons ons rykdomme daarheen stuur en dit doen ons wanneer ons aan die armes en behoeftiges meedeel. Daarom striem hy die Rooms-Katolieke priesters so wat die kerkvolk beweeg om geld wat aan die armes gegee moes gewees het, te bestee aan die bou van tempels, die oprigting van beelde en om kosbare kledingstukke te koop (Inst. 4.5.18). In 'n preek oor die agste gebod merk hy op dat wanneer ek sien dat 'n anne onderdruk word en ek probeer nie om hom te help nie, dan is ek medepligtig en medeskuldig (Calvyn, s.j.:172).

\subsubsection{Mens en natuur (heerskappy)}

Calvyn is baie eksplisiet in sy siening oor die mens se heerskappy oor die skepping: "Ook die opvatting van die mense wat die gelykenis van God (stel) in die heerskappy wat aan die mens gegee is, ... is nie aanneemlik nie " (Inst. 1.15.4). In sy kommentaar op Genesis 1:26 sê hy egter dat die menslike heerskappy oor die skepping 'n kiein deeltjie van die beeld vorm (Comm. Gen. 1:26). Interessant is sy opmerking dat "selfs in elke afsonderlike deel van die wêreld glinster daar in elk geval sekere spore van die heerlikheid van God" (Inst. 1.15.3), sodat Torrance (1977:35) konkludeer dat Calvyn in tweërlei sin oor die imago Dei handel: in algemene sin weerspieël die ganse skepping die heerlikheid van God en in besondere sin reflekteer die mens die heerlikheid van God deur 'n intelligente respons op die Woord. Die ganse skepping verbeeld God, maar die mens verbeeld Hom op ' $n$ besondere wyse (Engel, 1988:38-42).

Vandag betrek talle teoloè die beeld op natuurbeheersing (vgl. slegs Helberg, 1980:21; Hoekema, 1988:74, 78-80), hoewel sommige dit meer sien as die resultaat gevolg van die beeld (Vriezen, 1966:447; Durand, 1982:164; Wentsel, 1987: 588, 594, 613) of as doel daarvan (Bavinck, 1978:206, 215; Von Rad, 1966:160). Vos (1982:131-141) merk hieroor op dat die mens in Genesis 1 as heerser geteken word en in Genesis 2 as dienaar sodat die somtotaal van hierdie mensbeeld neerkom op dienende heerskappy - ' $n$ tekening van die mens wat die beeld van Christus weerspieël. Wolff (1974:159-165) verstaan die beeld as die mens (die mensheid) se (dienende) heerskappy oor die aarde en diere (die mens self is hier uitgesluit). Hy wys in hierdie verband op die Oud-Oosterse gebruik waarvolgens die oprigting van die standbeeld van 'n koning op sy heerskappy in daardie gebied gedui het (Wolff, 1974:160).

Jónsson (1988:219 e.v., 224) konkludeer na 'n breedvoerige ondersoek dat die funksionele interpretasie vandag die grootste konsensus onder teoloe het, naamlik "man's sharing in the dominion of God" en dat die enigste werklike altematief "the relational or Barthian interpretation" is (Jónsson, 1988:223). 
Samevattend kan gesê word dat dit in die beeld van God daarom gaan dat die ganse mens God sal reflekteer en dat hierdie begrip 'n veel juister omskrywing bied as die ander twee gangbare begrippe, te wete representeer en respondeer. Die mens moet God se volmaaktheid en barmhartigheid, sy liefde en vergewensgesindheid, sy heiligheid en geregtigheid, sy medemenslikheid en dienende heerskappy in hierdie wêreld weerspieël. Die mens mag daarom nie ' $n$ afbeelding van God maak nie (Tweede Gebod) omdat hy self beeld van God moet wéés. Met só ' $n$ benaderingswyse is die beeld meer as net ' $n$ relasie tot God al is die relasie fundamenteel vir die verstaan van die beeld. Anders gesê, die beeld gaan nie in die relasie op nie (soos by Thielicke, vgl. Berkouwer, 1957:147; Berkhof, 1973: 191,196 ), sodat die waarskuwing teen relasionisme hier op sy plek is (Stoker, 1967:97). 'n Mens kan immers kwalik 'n verhouding weerspieël, maar vanweë die verhouding kan die méns self spieëlbeeld van God wees. Die beeld beteken om God te weerspieêl, om Christus te vertoon. Soos Calvyn sê: Die mens is spieëlbeeld van die heerlikheid van God (Inst. 1.15.4).

\subsubsection{Siel en liggaam}

Die aspek van die mensbeskouing van Calvyn wat seker die meeste weerstand opgeroep het en waar die filosofiese invloed die duidelikste aantoonbaar is, word vervolgens bespreek. Dat 'n Skrifteoloog soos Calvyn oor siel en liggaam so filosofies kon teologiseer, is moeilik verstaanbaar. So konkludeer Van der Walt (1978:252): "A large part of his anthropology cannot stand the test." En hy is nie die enigste wat oor hierdie aspek kritiek uitgespreek het nie (vgl. slegs Berkhof, 1973:189; Duvenage, 1981:146, 148; Wentsel, 1987:606; Faber, 1990:280, met verwysing na Vollenhoven). Spykman (1992:234) erken ruiterlik: "Calvin's view of man therefore stands as the least reformed element in his theology."

Engel kom egter tot totaal ander konklusies. Sy bestry die tradisionele standpunt dat Calvyn 'n spiritualis, dualis en Platonis is (1988:169, 171, 173, 174; vgl. Noordegraaf, 1990:35, 55). Engel oordeel dat Calvyn vanuit die perspektief van God as skepper en verlosser die cenheid van siel en liggaam beklemtoon, maar vanuit die perspektief van die mens word die ongelykheid van siel en liggaam belig (Engel, 1988:168, 170). Sy vestig tereg die aandag daarop dat Calvyn teen verskillende fronte geveg het: teenoor die Anabaptisme en Humanisme handhaaf Calvyn die onsterflikheid van die siel en teenoor die Libertinisme die geskapenheid van die siel (Engel, 1988:152-161). Geheel oortuigend is haar argumente egter nie. Eerstens veronderstel haar denke nog te veel die twee-substansieleer (vgl. "two substances"- Engel, 1988:181); tweedens beroep Calvyn hom eksplisiet en bevestigend op Plato; derdens is dit ' $n$ vraag of Engel aan die gevaar van skematisme ontkom het wat veroorsaak het dat sy Calvyn te veel vanuit ' $n$ bepaalde en vooraf-opgestelde denkskema geïnterpreteer het. 
Daar is reeds terloops gewys op watter belangrike plek die siel-liggaamrelasie in die antropologie van Calvyn inneem. Dis vir Calvyn 'n onbetwisbare sekerheid dat die mens uit twee dele, naamlik siel en liggaam bestaan (Inst. 2.14.1) (vgl. veral sy Psychopannychia) (vgl. Quistorp, 1955:hfst.2). Die liggaam word dan as "aardse gevangenis" omskryf (Inst. 1.15.2, 3.6.5; 3.9.4; 3.15.1; 3.25.6) en na die siel word verwys as die "edeler" of "vernaamste deel" van die mens (Inst. 1.15.2). Die siel is aan die liggaam geheg en "woon daarin soos in 'n tuiste" (Inst. 1.15.6) waaruit hy uiteindelik "bevry" word (Inst. 1.15.2). Hoewel die siel (of gees) deur God geskape is (Inst. 1.15.2, 5), is dit "onsterflik" (Inst. 1.15.2), soos Plato tereg sê (Inst. 1.15.6), want dit leef na die dood voort. Calvyn (Calvin, 1982:119-158; Balke, 1977:318-323) opponeer gevolglik die Anabaptiste omdat hulle die sieleslaap (sou) aanvaar het. Ons het ook gesien dat die siel die "eintlike setel" van die beeld van God is, hoewel die liggaam nie heeltemal uitgesluit was nie (Inst. 1.15.3).

Die siel word in twee eienskappe verdeel naamlik verstand en wil (Inst. 1.15.7), met die verstand as die gids en bestuurder van die siel en die wil wat die wense van die verstand opvolg. Die verstand onderskei goed en kwaad, reg en onreg (Inst. 1.15.8) maar die mens het helaas deur sy eie wil in sonde geval.

Die Platoniese digotomiese mensbeskouing kom duidelik na vore; trouens, Calvyn verwys ook goedkeurend na Plato (Inst. 1.15.6). Op grond hiervan ontstaan die vraag hoe dit alles moontlik is.

In 'n verantwoorde beoordeling van Calvyn moet ' $n$ aantal belangrike gegewens in berekening gebring word (vgl. Faber, 1990:242-250). Allereers moet verreken word dat Calvyn oor die liggaam as tronk praat vanuit die perspektief van die sonde. Voorts moet onthou word dat hy jubelend oor die menslike liggaam as wonderwerk van God kan handel, soos duidelik blyk uit sy preek oor Job 10 (vgl. Bouwsma, 1988:134). Inderdaad is die ganse mens 'n pragtige produk van volmaakte vakmanskap (Eseg. 28:12). Talma (1882:30 e.v.) se negatiewe opmerkings oor Calvyn se liggaamsbeskouing moet dus as eensydig van die hand gewys word. Calvyn deurbreek die totaal negatiewe oordeel oor die menslike liggaam soos dit by Plato aangetref word en hierdie verskil sal nog duideliker aan die lig tree as hy oor die opstanding van die liggaam handel (Inst. 3.25) - iets wat vir die Platoniese denke natuurlik volkome onaanvaarbaar is.

Calvyn deurbreek die Griekse denke op 'n verdere punt as hy daarop wys dat die siel uit genade onsterflikheid ontvang en dit nie as 'n inherente kwaliteit besit nie, verder bestaan die siel ook nie vir ewig sonder die liggaam voort nie maar mét die liggaam (Wendel, 1978:174-175; Faber, 1990:248). Die idee van die onsterflikheid van die siel moet ook nie oorspan word nie aangesien die Griekse invloed hoe langer hoe meer op die agtergrond geraak het (Wendel, 1978:173). 
Teen die gedagte van 'n onsterflike deel van die mens, naamlik 'n onsterflike siel, het daar verset gekom (Van der Walt, 1982:73; Durand 1982:185, en 177, met verwysing na Cullmann; Spykman, 1992:239-240), aangesien die dood volgens die Skrif die totale mens tref en nie net 'n gedeelte van die mens nie. Die Skrif handel, vanuit Christus, wel duidelik oor die oorwinning oor die dood, maar die troos van hierdie oorwinning is nie geleë in 'n stukkie mens (siel) wat die dood vryspring nie, maar daarin dat God sy kinders deur die dood heen vashou (vgl. Luk. 23:43; Fil. 1:23) en uiteindelik aan hulle die opstanding van die liggaam, onverganklikheid en onsterflikheid skenk (1 Kor. 15) (vgl. Berkouwer, 1957:272299; Durand, 1982:176-187). Die Skrif is ook weinig geinteresseerd in die sogenaamde tussentoestand omdat die volle aksent op die opstanding val. Die tussentoestand wat in die Bybel ter sprake kom, dui ook nie op die tyd tussen sterwe en opstanding nie maar op die tyd tussen wedergeboorte en opstanding (Kol. 3:3-4) (Durand, 1982:186, 188).

Calvyn het die Platoniese mensbeskouing op ten minste vyf punte deurbreek (alhoewel hy die dualistiese paradigma hanteer het) :

* Die groter waardering van die menslike liggaam as skepping van God.

* Die siening dat die siel deur God geskape is en nie van ewigheid af bestaan nie.

* Die beskouing dat die siel nie inherente onsterflikheid besit nie, maar dat die onsterflikheid deur God geskenk is.

* Die insig dat die siel nie reïnameer nie, maar in teenwoordigheid van God bestaan.

* Die geloof aan die opstanding van die liggaam.

Onteenseglik sou Calvyn dit vir hom - en ons - veel makliker gemaak het indien hy hier nader aan die Skrif gehou en die (Skrif-)terme nie met filosofiese inhoude gevul het nie. Hoewel ons hom hier dus nie kritiekloos kan navolg nie, moet ons tog waardering daarvoor hê dat hy op die mees wesentlike punte (veral rondom die opstanding) die Platonisme deurbreek het. Daarby moet ons in gedagte hou dat dit nie net die dualistiese mensbeskouing is wat probleme oplewer nie; ook die monistiese model lewer sy kwota vrae sodat vandag al meer gedink word aan 'n psigosomatiese benadering in die antropologie (vgl. Cooper, 1989). Die Heidelbergse Kategismus 22:17 moet ook nie in Grieks-Platoniese sin vertolk word nie, maar vanuit 'n Bybels-Christologiese perspektief (vgl. Van Genderen \& Velema, 1992:753; vgl. ook die kritiek van Berkouwer, 1957:237) 


\subsection{Die roeping van die mens}

\subsubsection{Wêreld myding of wêreldwyding}

Dit is waar dat Calvyn soms sterk uitdrukkings in verband met die aardse lewe gebruik het - volgens Velema (1974:35) "te sterk". So merk hy op dat ons die wêreld moet "versaak" (Inst. 2.15.5), dat ons die teenswoordige lewe moet "verag" en "vertrap" (Inst. 3.9.1; 3.10.4) en dat hierdie wêreld vir ons "waardeloos" moet word (Inst. 3.9.2).

Calvyn maak hierdie uitsprake egter binne die konteks van die "oordenking van die toekomstige lewe" en in 'n vergelyking van hierdie lewe met die toekomstige lewe; dit is met ander woorde nie geïsoleerde uitsprake wat op hulleself staan nie. Hierby moet in gedagte gehou word dat Calvyn van bestaande uitdrukkings gebruik gemaak het (Holwerda, 1984:320). Hy probeer tussen die rotse van asketisme en sekularisme/materialisme deurstuur en hy wil reg laat geskied aan die Bybelse motiewe van vreemdelingskap en pelgrimskap. Daarom haas hy hom om by te voeg dat "gelowiges hulle egter daaraan moet gewoond maak om die huidige lewe op so 'n manier te verag dat hulle nie 'n afsku daarvan of ondankbaarheid teenoor God verwek nie" (Inst. 3.9.3). "Ons moet die lewe op aarde sekerlik nooit haat nie, behalwe in soverre dit ons aan die sonde onderhewig hou ..." (Inst. 3.9.4).

Dit is nodig om ietwat breër in te gaan op die belangrike opmerking van Holwerda, naamlik dat Calvyn in hierdie verband aangesluit het by (reeds lank) bestaande uitdrukkings soos wat byvoorbeeld in Thomas à Kempis se De imitaione Christi (1441?) te sien is - of wie die skrywer van hierdie veelgelese boek ook al mag wees. Wanneer hierdie boek nagegaan word, wemel dit inderdaad van uitsprake oor die 'veragting' van die aarde, trouens die opskrif van die heel eerste hoofstuk verwys reeds daana: "De imitatione Christi et contemptu omnium vanitatum mundi." Op talle plekke in die boek van Thomas à Kempis word daarna verwys om die wêreld of wêreldse goed te 'versmaai' en te 'verag' $(1977: 4,44,57,108,152,165)$, ja 'volkome (te) verag' ( $\dot{A}$ Kempis, 1977:43, 126). Om twee aanhalings deur te gee :

'Hy leer hulle om die aarde te verag,

en die hemelse lief te hê,

die wêreld maar na te laat

en na die hemelse bedags en snags te verlang' (À Kempis. 1977:96)

en:

'Wil jy die ewige lewe besit, verag die teenswoordige' (Á Kempis, 1977: 198). 
Van hierdie boek sê Duvenage (1954:25-31) onder andere dat dit mank gaan aan wêreldversaking en egosentrisme, hoeveel waardering daar andersins ook al mag wees, gesien die deformasie in die kerk van daardie tyd. Tereg merk Berkouwer (1949:169-170) op dat die navolging van Christus nêrens in die Skrif met isolering van die wêreld verbind word nie.

Dit is insiggewend dat dieselfde uitdrukking ook in die bekende Doopsformulier gebruik word waar gesê word dat ons "die wêreld moet versaak" (of daarvan "afsien"), maar dat daar nooit teen hierdie uitdrukking opspraakwekkende beswaar gemaak is nie. Wielenga (1920:109-112) skryf in sy bekende kommentaar op hierdie formulier dat hierdie uitdrukking nie verkeerd verstaan moet word as Doperse wêreldmyding of Roomse asketisme nie en dat dit nie gaan oor 'n afsien van die wêreld (as skepping) en die roeping in die wêreld nie, maar van die sonde van die wêreld ( 1 Joh. 2:15, 1 Kor. 5:10).

Die 'Calvinisme' was nog nooit op wêreldmyding afgestem nie maar wel op wêreldwyding. Calvyn het hom sy lewe lank verset teen 'n Doperse ontduiking van die mens se aardse roeping (Balke, 1977:261-313). "No one has emphasised more than Calvin our duty to serve God in daily life and in outward conduct" (Wallace, 1961:30). Calvyn laat daarom nie na om spesifiek oor die huidige lewe en die gebruikmaking van hulpmiddels te handel nie (Inst. 3.10).

Alle seëninge van die lewe is gawes van God, maar die mens, as pelgrim ('n telkens terugkerende motief: Inst. 3.7.3; 3.9.4-5; 3.10.1), moet waak teen onbeheerstheid en oordadigheid en hom instel op 'n regmatige gebruik van die gawes (Inst. 3.10.1). Hy mag gebruik wat hy nodig het en wat hy kan geniet (klere, wyn, olie, blomme, goud, silwer, ivoor en marmer) (Inst. 3.10.2).

Die aardse goed moet ' $n$ bydrae lewer tot ons roepingsvervulling, dit moet lei tot kennis van, dankbaarheid teenoor en liefde en eerbied vir die Gewer daarvan (Inst. 3.10.3). Calvyn pleit daarvoor dat gelowiges deugde soos geduld, matigheid en tevredenheid sal beoefen en altyd bereid sal wees van hulle rentmeesterskap rekenskap te gee (Inst. 3.10.4-5).

Die gelowige leef onder die universele koningsheerskappy van Jesus Christus (regnum Christi) en hy moet die lig van die evangelie op alle lewensterreine laat val. God moet oral gehoorsaam word: die ganse lewe is diens aan God (pro Rege). Calvyn was nie geïnteresseerd in ' $n$ verlossing uit die wêreld nie maar in 'n verlossing van die wêreld (Kolfhaus, 1949: 107). Wat Calvyn verwerp het, was nie die wêreld nie, maar die sonde van die wêreld.

Calvyn was ook nie net in die 'siel' van die mens geïnteresseerd nie, want hy skryf aan Sadoletus dat dit in die Christelike lewe om méer gaan as om die saligheid van die eie siel te soek en te beveilig (Runia, 1970:33). 


\subsubsection{Beroep en roeping}

Die roepingsmotief - die vocarlo Dei - is een van die kardinale aspekte van die mensbeskouing van Calvyn. In die slotgedeelte wat handel oor hoe ons die huidige lewe moet gebruik (Inst. 3.10.6), bring hy die roepingsgedagte na vore en stel dat die roeping van die Here (sowel by individue as by owerhede) "die beginsel en fondament (is) om in elke saak goed te handel". In so ' $n$ benadering is daar geen plek vir die standpunt dat sommige werk minderwaardig is nie: "Geen taak (kan) so onbeduidend en gering wees dat dit nie voor God se aangesig skitter en uiters kosbaar geag word nie, mits jy maar jou roeping gehoorsaam" (Inst. 3.10.6).

Calvyn onderskei tussen roeping (vocatio) en roepings (vocationes), tussen primêre en sekondêre roeping, tussen roeping as burger van die koninkryk van God en die verskillende roepings in die samelewing (vgl. Inst. 3.24.8)(vgl. Duvenage, 1981:273-275; Aalders, 1943). In al ons lewenshoudings moet ons ons oë op die roeping van die Here hou, sê Calvyn (Inst. 3.10.6). Die Gees van die Here rus mense ook toe om hulle roeping te volbring (Inst. 2.2.17). Goeie werk is die vrug van roepingsvervulling (Inst. 3.14.19). Vandaar dat Calvyn hom ook so positief oor menslike arbeid kon uitlaat. Hierdie arbeidsdrang en roepingsywer is deur sommige (Max Weber) selfs (ten onregte) gesien as een van die redes van die ontstaan van kapitalisme (vgl. Van Wyk, 1984:23-24).

\subsubsection{Natuur en kultuur}

Ons het reeds daarop gewys dat Calvyn geen asketiese lewensvisie gehad het nie en dit sou korrek wees om te stel dat hy sowel teen kultuurindifferentisme as kultuurabsolutisme gekant was. Hy het gewaak teen minagting van die kultuur én verafgoding daarvan.

Volgens Calvyn is beeldhoukuns en skilderkuns gawes van God en dit kan suiwer gebruik word tot eer van God en die welsyn van die mens (Inst. 1.11.12). Die Gees van God skenk voortreflike gawes, soos skone kunste, wetenskap, regsgeleerdheid, filosofie, geneeskunde en wiskunde tot nut van die mensheid (Inst. 2.2.14-17)(vgl. Van der Walt et al., 1982a:287-299, 300-313). Die mate waarin profane skrywers die waarheid gevind het, toon die oorvloedige seeninge wat God aan die gevalle mens nagelaat het (Inst. 2.2.15). Die volle kultuurlewe moes egter onder die heerskappy van Christus gestel word; daar was vir Calvyn geen neutrale terrein nie. Nou is dit natuurlik 'n vraag van die eerste orde hoe hierdie Christokrasie (teokrasie) in 'n plurale samelewing gerealiseer moet word, sónder dat die evangelie in 'n morele dwangsisteem ontaard. Daarom word daar vandag (tereg) veel klem daarop gelê dat die teokrasie 'n geloofshelydenis is (God regeer) en dat die teokrasie 'n geestelike karakter het wat veral in die kerk sy reinste 
vergestalting vind (of altans behóórt te vind); voorts dat Christene in die samelewing moet trag om deur oorreding en sonder dwang die groot beginsels van die koninkryk te laat realiseer.

Oor die teater was Calvyn, soos Augustinus (Confessiones 10.35) voor hom en Kuyper (1959:59) na hom, glad nie entoesiasties nie (Kolfhaus, 1949:215). Sy besondere waardering vir musiek is egter alombekend.

Dit gaan vir Calvyn om ' $\mathrm{n}$ gehoorsame en verantwoorde roepingsvervulling waarin die natuur tot kultuur omvorm word en wel tot eer van God (soli Deo gloria) en die welsyn van die mens. In hierdie omvorming van natuur tot kultuur moet die mens altyd besef dat hy rentmeester is en dat hy nooit met die skepping mag omgaan soos hy wil nie. In sy kommentaar op Psalm 24:1 merk hy op: "If they (men) should fail, the earth would exhibit a scene of desolation and solitude, not less hideous than if God should despoil it of all its other riches" (Comm. Psalms, 24:1). Hoewel Calvyn nie soos ons tans met enorme ekologiese vraagstukke gekonfronteer was nie, is dit in ooreenstemming met sy teosentriese denke dat alle uitbuiting en vernieling van die aarde as in stryd met die Skrif afgewys behoort te woord (vgl. Wallace, 1961:130-132). Die mens mag op aarde niks anders wees as 'n diénende heerser nie (Vos, 1982: 131-141).

\subsubsection{Kerk en koninkryk}

Die roeping van die mens kan natuurlik ook vanuit die perspektief van kerk en koninkryk benader word om sodoende meer reliêf daaraan te verleen. Vandag word algemeen in die teologie aanvaar dat die kerk die koninkryk moet dien (en nie andersom nie) (vgl. Wurth, 1959:73), en die vraag kan gestel word of Calvyn hierdie verhouding suiwer gesien het (vgl. Richel, 1942; Torrance, 1956; Bohatec, 1961; Ganoczy, 1968; Milner, 1970). Het die Platoniese ontologie nie ook hiér sy tol geeis nie waar 'n 'ideale hemelse' koninkryk met 'n 'veragte aardse' koninkryk gekontrasteer is? Is die siening van die koninkryk as 'geestelik' Bybels of Platonies gevul (Inst. 4.5.17; 4.20.12)? Is die kerk en koninkryk nie (soms) ten onregte (te veel) met mekaar geïdentifiseer nie (Inst. 4.1.13; 4.2.4; 4.5.9)?

Calvyn verwys meesal na die 'hemelse' koninkryk, sodanig dat dit soms skyn asof hierdie 'hemelse' koninkryk weinig met die aarde te doen het (Inst. 2.11.1; 2.15.3-6; 3.9.3; 4.20.1). Dit is 'n Joodse ydelheid, sê hy, om die ryk van Christus "onder die elemente van hierdie wêreld te soek en daar in te sluit" (Inst. 4.20.1). Tog "begin hierdie ryk reeds nou op aarde om in ons te werk" (Inst. 4.20.2), want deur sy Heilige Gees "buig, skik, vorm en stuur" die Here die menslike wil om heiligheid en geregtigheid na te streef (Inst 2.5.14-15).

In sy behandeling van die tweede bede van die Onse Vader handel Calvyn breedvoerig oor die koninkryk (Inst. 3.20.42). Hy definieer die koninkryk soos 
volg: "God regeer waar mense hulle sowel deur selfverloening as deur die veragting van die wêreld en hulle lewe op aarde, aan sy geregtigheid toegesê het om na die hemelse lewe te streef." Die mag van die Bose moet verbreek en die kerk moet wêreldwyd uitgebrei word. Die koninkryk van God staan in onlosmaaklike verband met vergifnis van sondes, saligheid en die volle lewe in Christus; in Christus is al die skatte van God se barmhartigheid geopenbaar, maar Hy eis berou (bekering) en vertroue op die beloftes van God (Inst. 3.3.19; vgl. 3.20.610). Dit is duidelik dat Calvyn die koninkryk van God tereg met die heerskappy van God in Christus verbind het, maar myns insiens het hy die ander dimensie van die koninkryk, naamlik as (wêreldomspannende) $r y k$, onderbeklemtoon.

Wurth (1959:59-68) vestig die aandag daarop dat Calvyn sy beskouing van die koninkryk teen drie fronte afgeskerm het: teen die Roomse ekklesiolatrie, teen die Anabaptistiese radikalisme en isolasionisme en teen die Lutherse dualisme. Kerk en owerheid het immers sy eie taak en terrein (Inst. 4.20.1; 4.21.3). Calvyn het sowel 'n kerkstaat as 'n staatskerk verwerp.

Die kerk, die gelowiges, as priesters, het 'n roeping om op aarde die koninkryk van God te dien. Maar het kerkvergaderinge ook hierdie roeping? Het Calvyn die profetiese roeping van die kerk in die samelewing genoegsaam beklemtoon? Ekklesiolatrie, oorheersing van die staat deur die kerk, het hy tereg afgewys (Inst. 4.21.11-16), maar het hierdie afuysing geskied ten koste van die profetiese roeping van die kerk? Het die beginsel van 'soewereiniteit in eie kring' uitgeloop op 'n introvertisme in eie kring? Het Kuyper (1959) Calvyn reg vertolk deur te oordeel dat die sogenaamde 'kerk as instituut' nie 'n profetiese roeping teenoor die staat het nie? Hierdie is almal vrae wat deur die kerkleer van Calvyn opgeroep word (vgl. Duvenage, 1962:105-110).

\subsubsection{Owerheid en onderdaan}

Calvyn sluit sy Institusie (Inst. 4.20) op 'n (vir 'n dognatiek) sonderlinge wyse af deur vir 'n burgerlike regering aandag te vra. Hy behandel eerstens die taak van die regering en daama die verantwoordelikheid van die onderdane. In die bespreking hiervan word die aandag vanselfsprekend slegs op die hoofmomente en relevante aspekte gevestig (vgl. Van Wyk, 1984:19-21).

Calvyn begin deur 'n duidelike onderskeid te maak tussen die regering van Christus en die burgerlike regering (Inst. 4.20.1). Tog wil hy nie hierdie twee regeringsoorte totaal van mekaar skei nie en wys hy aan die burgerlike regering die opdrag toe om die uiterlike godsdiens te beskerm, die gesonde leer van die vroomheid en die toestand van die kerk te verdedig, die lewe in te rig tot die samelewing van mense, die sedes te vorm volgens burgerlike geregtigheid, mense met mekaar te verenig en die algemene vrede en rus te bevorder (Inst. 4.20.2). 
Calvyn beskou die owerheid as van goddelike oorsprong. Die amp van die owerheid kom van God en Hy beklee die owerheid met gesag (Inst. 4.20.4). Burgerli$k e$ mag is ' $n$ roeping, dit is heilig en wettig voor God en die mees eervolle roeping van almal (Inst. 4.20.4). Dit is duidelik dat Calvyn hom op hierdie punt van die Anabaptisme distansieer (Inst. 4.20.7). Hy is egter nie baie bekommerd oor die nuttigste regeringsvorm nie, en of dit 'n aristokrasie, 'n oligargie of 'n demokrasie moet wees nie. Hy oordeel dat eersgenoemde waarskynlik die beste is, of dan 'n mengsel van die eerste en die laaste (Inst. 4.20.8). Die hoofsaak is nie wie regeer nie maar hoe regeer word.

Wat die taak van die regering betref, verwys Calvyn na 'n wye reeks sake. Hy aanvaar dat die regering die godsdiens moet beskerm, asook onskuld, sedelikheid, eerbaarheid en rus en verder moet die algemene welsyn en vrede vir almal bevorder word; die regeerders het die gesag om kwaaddoeners en misdadigers te straf en om onskuldiges te beskerm. Samevattend - die regeerders moet reg en geregtigheid laat geskied (Inst. 4.20.9). As hanteerders van die swaardmag, mag die regeerders ook die doodstraf toepas (Inst. 4.20.10). 'n Deel van hulle taak is ook om in uiterste gevalle aan 'n (regverdige) oorlog deel te neem (Inst. 4.20.1112). Owerhede beskik ook oor die reg om belasting te hef (Inst. 4.20.13) en om wette te mak (Inst. 4.20.14-16), maar dan wette wat gedra word deur die beginsels van geregtigheid, billikheid en liefde. Ook die regspraak is deel van die owerheidstaak (Inst. 4.20.17-21).

Maar waarin bestaan die plig van die onderdane? Die onontkombare antwoord is dat die plig van die onderdaan saamgetrek word in eerbied vir en gehoorsaamheid aan die owerheid, nie soseer teenoor die persone van die owerheid nie as teenoor hulle amp (Inst. 4.20 .22 e.v.). Hierdie eerbied reik besonder ver, dit geld selfs die "allerslegste tiran" (Inst. 4.20.26) en onderdane is dit "tot die uiterste toe" aan die owerhede verskuldig (Inst. 4.20.29). In hierdie opsig is daar egter één uitsondering en dit is dat die gehoorsaamheid aan die owerheid "ons nie mag afvoer van die gehoorsaamheid aan God nie", in so 'n geval moet God meer gehoorsaam word as die mens (Hand. 5:29) (Inst. 4.20.32). Calvyn verwys ook na "die vryheid van die volk" (Inst. 4.20.31) en daar is verskil van mening of hy hier oor die godsdiensvryheid van die volk handel (wat dus wesentlik dieselfde is as wat reeds genoem is) en of hy oor politıeke volksvryhede handel. Indien die Institusie 4.20 .32 in samehang met 4.20 .8 gelees word, kan dit inderdaad ook op politieke vryhede slaan (De Kroon, 1991:151,154). Andersyds dui die formulering in die enkelvoud "die uitsondering" (Inst. 4.20.32), dit wil sê nié méérdere uitsonderings nie, weer sterk in die rigting van slegs godsdiensvryheid.

Die vraag is egter watter vorm sodanige verset teen die owerheid mag aanneem geweldloos of gewelddadig? Dit val op dat Calvyn se versetsteorie 'n bepaalde ontwikkeling deurgemaak het. Aanvanklik kies hy baie sterk vir lydelike verset 
(vgl. die eerste uitgawe van die Institusie van 1536), maar later, toe die vervolging van die Protestante toegeneem het, ontwikkel hy die teorie van aktiewe verset (Manenschijn, 1984:170-171; 183-184; De Kroon, 1991:149). Hy konkludeer dat in sulke uiterste gevalle die "volksmagistrate" ( populares magistratus) (en nie individue, die massa of laer magistrate nie, vgl. Douma, 1984:196; Manenschijn, 1984:174) die reg het om die willekeur van konings "te bedwing" (Inst. 4.20.31) - 'n aspek wat Calvyn breër uitwerk in sy preke, kommentare en briewe. Dit is egter opvallend dat, hoewel Calvyn die reg tot verset teoreties gebillik het, hy gelowiges prakties nooit daartoe aangemoedig het nie (Watanabe, 1991:122).

Opsommend kan Calvyn se standpunt oor aktiewe verset (ius resistendi) soos volg weergegee word:

* Aktiewe verset is ' $n$ allerlaaste middel nadat alle vreedsame middels gefaal het.

* Verset mag slegs deur (demokraties verkose) volksmagistrate onderneem word en nie deur individue, die massa of laer magistrate nie (onderdane mag nie verder gaan as lydelike verset nie).

* Aktiewe verset mag slegs onderneem word in gevalle waar godsdiensvryheid (en moontlik ook volksvryheid) aangetas is.

* Daar moet soveel moontlik menslikheid aan die dag gelê word sodat daar 'n verantwoorde verhouding tussen middel en doel, oorsaak en gevolg sal wees.

Dit is duidelik dat daar vanuit die standpunt van Calvyn nie oorhaastig gekonkludeer mag word dat die standpunt van 'n rewolusie geregverdig is nie (Manenschijn, 1984:184) en dat daar baie duidelik tussen 'n rebellie en 'n rewolusie onderskei moet word (contra Bosch, 199lb:134). Daarby kan daar ook kritiese vrae aan Calvyn gestel word ten opsigte van sy Skriftuurlike fundering van gewelddadige verset.

\subsection{Die bestemming van die mens}

Van alle aspekte van Calvyn se teologie is sy eskatologie seker die swakste ontwikkel, in elk geval wat die Institusie betref. "Calvin has never been famous for his eschatology" (Holwerda, 1984:311, vgl. Quistorp, 1955). Holwerda (1984: 339-340) is volkome korrek as hy opmerk dat die eskatologie van Calvyn veel sterker in sy kommentare as in die Instıtusie ontwikkel is. Ongelukkig het Calvyn geen kommentaar op die boek Openbaring die lig laat sien nie. Dit verbaas nie dat Niesel (1980) in sy bekende boek oor Calvyn feitlik geen aandag aan die eskatologie bestee nie. 
Ons het reeds gesien dat die meditatio futurae vitae (Inst. 3.9) vir Calvyn van groot belang is, sodat tereg opgemerk is dat die eskatologiese perspektief vir hom onmisbaar is (Kolfhaus, 1949:542). Nadenke oor die "geluksalige opstanding" is noodsaaklik (Inst. 3.25.1-2); tog gaan Calvyn se eskatologie in die Institusie in 'n groot mate op in 'n besinning oor die laaste opstanding (Inst. 3.25), sodat die aspek van ' $n$ universeel-kosmiese dimensie onderontwikkel is.

\subsubsection{Die tussentyd}

Calvyn wys die chiliasme (saam met Augustinus) sonder meer as "kinderagtig" af (Inst. 3.25.5). Die Skrif leer dat ons tans in die tussentyd tussen koms en wederkoms leef (Quistorp, 1955:19) en die kruis en opstanding van Christus is die groot eskatologiese wentelpunt in die wêreldgeskiedenis (Holwerda, 1984:323324). Ons verkeer tans in die spanningssituasie tussen die 'reeds' en die 'nog nie (voltooid nie)'. Calvyn distansieer hom van die statiese Middeleeuse opvatting van die geskiedenis en aanvaar, vanuit die motief van die soewereiniteit van God en die uitverkiesing, 'n veel dinamieser visie. Gevolglik beïnvloed geskiedenis en eskaton mekaar wedersyds: die geskiedenis stu voort na die voleinding (pushview) maar die voleinding trek die geskiedenis ook aan (pull-view) (Holwerda, 1984:313). Calvyn wys egter, so is reeds opgemerk, alle fanatisme en rewolusionisme af wat die koninkryk deur geweld wil realiseer (Holwerda, 1984:314, 341). Die koninkryk kom prosesmatig maar nie langs humanisties-ewolusionêre weg nie. Daar is by Calvyn geen sprake van kultuuroptimisme nie maar veel eerder van kultuurrealisme (Runia, 1970:45). Hy is maar alte bewus van die "eskatologiese voorbehoud', van die laaste oordeel waar alle menslike werk finaal geoordeel word. Al ons menslike arbeid en prestasies bring nog nie die koninkryk voort nie, want die koms daarvan is uiteindelik 'n daad van God. In ooreenstemming met Calvyn merk Jonker (1977:211) tereg op: "Hierdie wêreld met sy groei en toename, sy humanisering en beskawing staan nie in 'n direkte kontinuitteit met die koninkryk van God nie."

Deur sy uiteindelike bestemming in die eskaton in gedagte te hou, moet die mens hier en nou sy roeping op aarde vervul (vgl. Wallace, 1961:79-82). Die komende toekoms maak geensins ons daaglikse werk sinloos nie, inteendeel, dit gee juis daaraan sin.

\subsubsection{Die "tussentoestand"}

Calvyn wys 'n nuuskierige ondersoek na die "tussentoestand" (tussen dood en opstanding) van die hand (Inst. 3.25.6). Wat hy oor die "onsterflike siel" gesê het, word nie weer hier herhaal nie, behalwe deur te noem dat die siel na die dood voortlewe (Inst. 1.15.2). Die siel is bewustelik by God, daarom is daar ook nie 
sprake van 'n sieleslaap nie. Dit is gevolglik foutief om te sê dat die siel saam met die liggaam sal opstaan asof die volle mens gesterf het (Inst. 3.25.6).

Ook die Roomse leer van die vagevuur (wat betrekking het op voldoening wat siele van gestorwenes na die dood vir hulle sondes betaal) word deur Calvyn skerp afgewys (Inst. 3.5.6-10, vgl. 4.19:14). Hierdie leer tas immers die versoening deur voldoening deur Christus in sy wese aan, dit maak die kruis van Christus doelloos, dit verleen aan God se barmhartigheid 'n ondraaglike smaad, dit laat ons geloof struikel en vernietig: dis ' $n$ versinsel van Satan en lastering teen Christus. Die Skrifgetuienis (veral I Kor. 3:12-15) bevestig dit nie en die Skrif, wat ons hoogste maatstaf is, leer nêrens so-iets nie. 'n Beroep op 'n ou kerklike tradisie is gevolglik waardeloos.

\subsubsection{Die opstanding}

Alle klem val vir Calvyn op die opstanding van die liggaam en hiermee sou hy die verste gaan in sy deurbreking van die Platonies-idealistiese mensbeeld. Die siel sonder die opstanding van die liggaam is immers futiel Calvyn noem dat hierdie 'n "moeilike onderwerp" is maar die Skrif maak dit makliker vir ons deur te wys op die opstanding van Christus en die almag van God (Inst. 3.25.3-4, 8).

Wat die opstandingsliggaam betref, dink Calvyn reëel-Bybels: dis dieselfde liggaam wat opstaan (Inst. 3.25.7), dieselfde substansie, maar met ander kwaliteite (Inst. 3.25.8). Dis foutief om te sê dat die siel met 'n ander liggaam beklee sal word (Inst. 3.25.6-7).

\subsubsection{Die voleinding}

Die Skrif leer dat die volheid van die koninkryk nog kom (Inst. 3.20.42): die Antichris moet finaal verslaan word, die laaste gerig moet voltrek word en Christus moct kom om alles te voltooi.

Die verworpenes sowel as die uitverkorenes staan op (Inst. 3.25.9,12) en daar wag ' $n$ ewige geluksaligheid vir laasgenoemdes en 'n ewige straf vir eersgenoemdes (Inst. 3.25.5) - Wendel (1978:289) meen dat Calvyn huiwer om die gegewens oor die hel letterlik op te neem. Die doel van die opstanding is die ewige geluksaligheid, om deelgenoot te word van God se natuur, dit wil sê, God sal in al sy heiliges verheerlik word (Inst. 3.25.10). Almal sal in die hemel die ewige lewe en 'n besondere loon ontvang, hoewel nie gelyke heerlikheid nie (Inst. $3.25 .10)$.

Die vraag ontstaan dus of die ewige lewe juis in die hemel beleef word. Is die uiteindelike bestemming van die verloste mensheid dan nie op die nuwe aarde nie (2 Pet. 3:13; Op. 21:1)? Is Calvyn se eskatologie dan tog te 'idealisties', tog te 
individualisties en selfs te futuristies? Nee, antwoord Holwerda (1984:337-339), die kosmiese kontoere ontbreek nie. In sy kommentaar op Romeine 8:20 blyk hoe mens en wêreld, kerk en kosmos saam deel het aan die groot eskatologiese verwagting. "God will restore to a perfect state the world, now fallen, together with mankind"; ons weet egter nie hoe dit sal wees nie en ons moet in hierdie opsig ook alle spekulasie vermy (Comm. Rom. 8:21).

Samevattend kan gesê word: "Eschatology makes the world go round!" (Holwerda, 1984:338). En ons kan byvoeg: Eskatologie bring die mens en kosmos tot sy finale bestemming: Alles nuut! (Op. 21:5) en God alles in almal (1 Kor. 15:28). 